\title{
Manly Merchants
}

\author{
Commerce, Mobility and Masculinity among Afghan Traders \\ in Eurasia
}

\section{Magnus Marsden}

\begin{abstract}
This article explores intersections between masculinity, mobility, generation and commerce through the everyday lives of Afghan men who make up trading networks that are active across Eurasia. It is based on ethnographic fieldwork among Afghan traders in Ukraine's port city of Odessa and in the international trading city of Yiwu in China. Building on recent work in anthropology concerning the 'emergent' nature of Middle Eastern masculinities, the article brings attention to the flexible and adaptable nature of the notions of masculinity held and performed by mobile Afghan traders. It emphasises the need for such conceptions of masculinity to be treated historically and draws attention to the forms of caregiving that are especially important to the traders' intimate lives and self-understandings. The article also highlights the significance of complex notions of trust both to the traders' articulation of conceptions of manliness and to their everyday modes of securing a livelihood.
\end{abstract}

Keywords: Afghanistan, care, family, masculinity, merchants, trading networks

Popular and scholarly images of Afghanistan regularly revolve around the figure of the tribal warrior and his ability to endure hardship, fight battles and engage in heroic acts of conquest. Such timeless images of 'the warrior Afghan' overlook the fact that as early as the sixteenth century, notions of the warrior king as the model for leadership in Central Asia were giving way to an emphasis on forms of manly conduct closely related to the emergence of the bureaucratic state (Anooshahr 2008; cf. O’Hanlon 2007). But if historians have developed complex models for understanding manhood in the cultures and societies of the regions that currently make up Afghanistan (see also Edwards 1996), conventional depictions of contemporary Afghan men often remain 
wedded to the idea that masculine ideals in the country and its diasporas are determined above all by rigid and 'traditional' notions of honour, bravery and autonomy (e.g. Malik 2016). This article presents a more dynamic and multidimensional picture of the role played by models for and practices of masculinity in Afghanistan and its diasporas. It does so through a consideration of ethnographic material relating to mobile Afghan traders who work in a variety of settings across Eurasia. Beyond contesting one-sided images that suggest Afghan masculinity revolves around the twin notions of honour and bravery, the article addresses the intersection between mobility, masculinity and commerce, exploring the manifestation of these in the texture of the everyday family lives of the traders.

An expanding body of literature has explored the relationship between mobility and masculinity within the Middle East and among refugees from the region settled in Western Europe. Recently, this literature has questioned the value for the analysis of Middle Eastern masculinities of long-standing tropes in the study of masculinity such as 'hegemonic masculinity' and the 'male crisis' (e.g. Connell and Messerschmidt 2005). Studies have deployed, instead, the concept of 'emergent masculinities' (Inhorn 2012; Inhorn and Isidoros 2018) to identify and illuminate the nuanced ways men in the region and among its migrant communities have addressed and negotiated the wide range of pressures on their everyday lives. These pressures range from job insecurity arising from neoliberal modes of organising the economy to the painful and often stigmatising experience of being labelled as 'refugees' in the countries to which they have migrated. Ethnographic studies, for example, of Arab migrants and refugees in settings as diverse as Egypt (Suerbaum 2018) and Greece (Ingvars and Gíslason 2018) emphasise the ways in which Middle Eastern men are adaptable both in their conceptualisations and enactments of manhood. Such flexibility is especially visible in the new social, cultural and political environments to which they have migrated. Work focusing on the 'emergent' nature of masculinity has also recently enriched the understanding of gendered personhood in Afghanistan. In his study of Afghan Pashtun men, Andrea Chiovenda has distinguished between public cultural idioms of masculinity and the 'private meanings that such idioms assume' for his individual informants, arguing that resulting tensions lead individuals to become agents for change (2018: 65-66).

Masculinity's relationship to mobility has also been an important concern in study of Afghan migration. Alessandro Monsutti (2006) argues that migration is an integral feature of Afghanistan's society and economy. For Monsutti, migration is regarded in various Afghan communities as a rite de passage that marks the transition from youthfulness to manhood. For the Hazaras among whom Monsutti conducted multi-sited ethnographic fieldwork in Iran, Pakistan and Afghanistan, a key element of the experience of migration is the cultivation by young migrant men of masculine forms of selfhood - something achieved through the trials of travel and life away from home. For Hazara 
migrants, the ability to withstand the difficulties of life and labour represents a rite of passage on the path to manhood that eventually results in young migrants returning to their homes as marriageable young men before - more often than not - once more setting off on repetitive cycles of labour migration. Based on fieldwork conducted with Pashtun migrants in the United Kingdom and Pakistan, Nicola Khan (2014) has brought attention to the importance of practices such as the picnic trip (chakar) to the ways in which Afghan male migrants living in the UK address the confining experiences of labouring abroad while also expressing their desires for greater freedom.

This article builds on this rich body of literature by exploring the models of masculinity important to Afghans who explicitly identify themselves as being mobile traders (taajirhaa) and are mostly based in post-Soviet settings. Taking cue from recent scholarship on masculinity in the Middle East, it 'challenges preconceived ideas about the masculine spot' (Naguib 2015: 52; cf. Osella 2013), emphasising instead how masculinity is socially performed in specific spaces. A consideration of such performances reveals the masculinity of the traders is 'emergent' in the sense that men are contextually flexible and adaptive in terms of the notions of masculinity they deploy and enact. Ethnographically, however, rather than focusing on young and unmarried men, it explores the perspectives on manhood (mardigaari) evinced by men who describe themselves as being married (zandaar) and 'family men' (mardumhaa-ye baa faamil). Following Marcia Inhorn and Konstantina Isidoros (2018), examining the cases of individual married men who also belong to different generations brings attention to a range of intersections between mobility and masculinity in Afghan society, thereby further underscoring the emergent, shifting and historical properties of masculinity.

The article thus documents the lives of men who came of age during the Soviet occupation of the country in the 1980s, those who embarked on married life during the years of the civil war involving competing mujahidin factions, and others who transitioned from youth to adulthood in the initial years of the post-Taliban US occupation of the country in 2001/2002. Alongside this distinct ethnographic focus on married men, analytically the article emphasises the need to consider masculinity in relationship not only to mobility but also to the specific economic activities in which men are engaged, as well as to their professional social identities as 'traders'. Doing so evinces understandings of masculinity that are closely entwined not with one-directional 'migration' but rather with participation in the circulatory forms of mobility (Ho 2017) associated with commerce. There is an entwinement between commerce and mobility in the lives of these traders and resultantly the enactment of trust and 'trustability' comes to the fore as a critical component of manliness. ${ }^{1}$ Before turning to the ethnography, the article explores the wider context in which the traders lead their lives, addressing first the historical and cultural intertwinement between commerce, trust and masculinity and then the geographical configurations of Afghanistan's commercial communities. 


\section{Islam, Commerce and Masculinity}

An extensive body of anthropological literature has documented and theorised the relationship of Islamic doctrines and teachings to the ideologies of gender and personhood widely encountered in Muslim societies (Abu-Lughod 1986; Kurin 1984; Peletz 1994). Such studies demonstrate how traders understand and represent themselves as providing models for ordered sociality and morality. An issue under debate in this literature concerns the degree to which merchants are treated within the Islamic tradition as the embodiments of idealised forms of masculine behaviour. In Asia's urban Muslim settings, there are powerful if variable articulations between notions of masculinity and the figure of the merchant. It is commonplace in Asia's Muslim societies for men to be portrayed as better than women at controlling their carnal instincts and emotions ( $n a f s$ ) by using the powers of the rational intellect ( $a q l$ ). In turn, this supposedly Islamic model of masculinity is regarded as informing the ability of men to cultivate reputations for trustworthiness, rationality and piety - elements of selfhood that are also qualities widely regarded as being central for the exemplary merchant. According to this ideology, men are able to deploy the $a q l$ in order to maintain composure and self-control during the drawn-out forms of bargaining and negotiation that Clifford Geertz identified as being central to the activities of merchants operating in 'bazaar economies' (Siegal 1969; cf. Geertz 1973).

Anthropologists, however, have pointed to the problems that arise when this model is generally applied to Muslim societies. Suzanne Brenner, for example, demonstrated that in Java, women rather than men are regarded as being able to control their passions. In Javanese society, women are placed in control of the household finances and dominate trade across the region's market places and at a range of scales, from petty trader to wealthy merchant (1998: 30-31). Brenner suggests, however, that the particularity of Java's gendered economic roles emerges out of an interaction between Javanese and Islamic traditions. As a result, the notion that the merchant is equated in Islamic doctrine with the achievement of dominant forms of religiously sanctioned masculinity remains powerful and important in much of the literature.

The figure of the trader plays a more ambiguous role in Asia's rural Muslim societies, however. Ethnography conducted in tribal societies in Muslim Asia regularly highlights the extent to which 'tribesmen' associate trade and exchange not with the moral virtues of trustworthiness and piety but with weakness and immorality. Traders, indeed, are often regarded by tribespeople as being involved in un-Islamic activities (most especially that of usury). Furthermore, widespread tropes in Muslim rural societies depict itinerant traders as using the access to private spaces that their marginal roles in society bestows upon them to engage in immoral and dishonourable acts, notably illicit sexual relationships with women (Dresch 2006; Lindholm 1982; Marsden 
2005; Vom Bruck 2005). Similarly, in parts of rural Muslim Asia in which status hierarchy is an embedded feature of social structures and where traditions of aristocratic authority continue to be powerful and important, local ideologies regularly depict the willingness to trade as being a sign not of masculine rationality and self-control but rather its opposite: of the insatiable and uncontrolled thirst for wealth and money (Marsden 2005). In such contexts, then, both trade and the forms of mobility with which it is connected are associated with carnal desire and aspects of personhood that local gender ideologies frequently designate as being 'feminine'.

A significant analytical issue raised by such studies concerns the extent to which these models are able to address and illuminate historical transformations in gendered conceptions of personhood. The distinction between the models of idealised masculinity important in tribal and urban Muslim Asian societies in Asia have been complicated in recent years by scholarly recognition of the permeable nature of social boundaries, including of those between rural and urban societies. At one level, there is growing recognition of the critical role played by 'trading tribes' in the practice of long-distance commerce; such recognition has questioned the notion that traders and tribesmen form distinct social groups (Hanifi 2011; Hopkins 2008; Ferdinand 2006; Tapper 2008). At another level, new forms of political economy (often referred to as reflecting the characteristics of neoliberal capitalism) have undermined older socio-economic hierarchies, including the position of established merchant classes. Contemporary forms of political economy are associated rather with new socio-economic classes or status groups for whom 'entrepreneurship' is regarded as a primary economic activity, rather than trade and the maintenance of reputable forms of merchant life (e.g. Anderson 2011; Picard 2000). Scholarship exploring such emergent configurations of economy, politics and society has documented how actors increasingly seek to achieve social value for their modes of making a living in relationship to multiple and often conflicting moral reference points (Schielke 2009). Everyday modes of masculinity might be performed in a manner that reflects the value of adhering to conventional urban forms of social reputation and piety, to the honour-focused concerns of rural contexts and to the moral and ethical concerns of the globalised world (Schielke 2015). Recognition of such multidimensionality in Muslim moral worlds and the ways these inform varying notions of masculinity also challenges the simplistic notion that there are identifiably 'dominant' and 'marginal' masculinities (cf. Connell and Messerschmidt 2005). In place of such a binary way of exploring the relationship between different notions of masculinity as played out in particular individuals, societies and cultures, anthropologists increasingly focus on how men switch between different - sometimes contradictory - models of normative masculinity, often struggling to live up to the varying expectations they carry of manly behaviour and comportment (Marsden 2007, 2008; Osella 2013; Osella and Osella 2007; Pratt-Ewing 2008). 


\section{Reputational Spaces and the Family in the Global Trade in Chinese Commodities}

The merchants on whom this article focuses are mostly involved in the trade of small commodities between China and a variety of settings in West Asia and Eurasia. This form of trading activity is increasingly referred to by economic anthropologists as constituting 'globalisation from below', a concept that emphasises the relatively small scale and informal nature of such modes of doing business (Mathews et al. 2012). The trade in such commodities not only involves individual traders travelling to China to purchase commodities. Traders, rather, are also often based in the Chinese cities that are critical for procurement of the goods in which they deal (notably Guangzhou, Yiwu and Beijing). Living in such cities, they carry out a range of services that are offered to visiting traders, including the provisioning and checking of goods, oversight over the completion of Chinese customs procedures and interactions with international shipping companies. As a result, the traders are highly mobile but have also formed established communities in China, as well as in the countries in whose markets they sell the commodities in which they deal (principally in Russia, Ukraine and Belarus). ${ }^{2}$

While the commodities in which the traders deal are mostly low value, the financial and reputational stakes of being involved in such business activities are substantial, both for individual traders and for the extensive networks they form. Most of the traders who travel to China run small wholesale ventures in markets in Eurasia, seeking to earn sufficient profits from their commercial activities to sustain their business, support their families in the countries in which they are based and send remittances to their extended families in Afghanistan and in the neighbouring countries in which they are regularly located as refugees or migrants, especially Iran, Pakistan and Tajikistan (Harpviken 2009). Given the intensely social nature of the stakes involved, it is not surprising that questions of trust (ihtibaar) and reputation (izzat; naam) are central to the social identities of the traders. While the markets in which these men work are fiercely competitive, seeking to undercut the business activities of a fellow Afghan to a degree that puts them out of business is regarded as being immoral work. Likewise, the commission agents based in China are involved in forms of work that require the unrelenting performance of honesty and personal integrity - values associated with the masculine ideals of the traditional Muslim merchant (taajir) - even if in their everyday lives and practices they rarely meet these standards.

Traders based in Ukraine or Russia often ask China-based commission agents to purchase and transport to them commodities that are running low in their warehouses. To do so, the trader requesting the commodities will send photos of the item he requires (mostly using the Chinese app WeChat) to the commission agent in China; the commission agent will then use the photograph to locate the commodity at a market in China (mostly the Futian market 
in the international trade city of Yiwu in eastern China's Zhejiang province). Commission agents may also travel to a factory to request the production of items if the trader who is based outside China has placed a substantial order. Commission agents, then, have access to critical and sensitive information about the types of commodities, as well as designs and colours that are selling particularly well in the markets in which Afghan traders work. Traders are well aware of this, and regularly accuse commission agents of providing such information to their competitors. Alternatively, agents might seek to start their trading operations in the market in which their client works, initially by sending goods and asking customers to sell them in return for sharing the profits on a percentage basis, and later by themselves opening a business in situ. Such activity on the part of China-based commission agents can have serious consequences for traders who have spent years building up businesses far away from home. In this respect, trust is central to the relationship between commission workers based in Yiwu and their clients in the city's commercial outposts: it is an important element of the financial exchanges between such actors, but also critical to their understandings of how information is handled and shared.

The traders deploy multiple resources in order to fashion themselves as 'trustworthy and clean-named merchants'. Importantly, the resources deployed in such constructions of masculine selfhood vary from context to context. For the commission agents in Yiwu, Islam plays a central role in the cultivation of the figure of the trustworthy trader. The agents in Yiwu place considerable emphasis, for example, on the public display of their credentials as being pious Muslims. They do so through playing an active role in the organisation of religious events and social gatherings in the city, especially during the holy month of Ramadan, when the traders collectively organise iftar meals and attend evening tarawih prayers. The traders also make financial contributions to support religious activities such as bringing to China religious experts from India in order to allow Muslims in the city to listen to the complete recitation of the Qur'an (khatum) that takes place over the course of the holy month. On a more day-to-day basis, the traders in Yiwu demonstrate their commitment to Islamic normative concerns and the moral community of Muslim Afghans in the city more generally by attending and hosting prayer events (faitha) that mark the deaths of the relatives of Yiwu-based traders. Family life is also an important domain in relationship to which traders mark themselves out as being trustworthy and pious. Traders in Yiwu take purposeful steps to publicly display the ways in which they maintain 'traditional' forms of Afghan family life in the modern context of Yiwu. Most traders based in Yiwu live without their families. Yet, as we shall see, those who do bring wives and children to the city emphasise that they follow rigid purdah norms even in China. This entails traders observing the distinction between public and private space and actively shunning the participation of their families in mixed gender social events. Such commitment to public Islam among commission agents in Yiwu reflects the 
fact of their having migrated to Yiwu from Afghanistan, a country with which they all maintain close social and commercial ties.

By contrast, the traders who visit Yiwu from the Eurasian contexts in which they work are more sceptical about the degree to which public commitment towards Islamic symbols and rituals marks individual men out as being trustworthy and reputable. Such scepticism is partly a reflection of the role that traders based in such contexts played in the pro-Soviet Afghan government during the 1980s and earlier. Many of these traders were affiliated to the proSoviet regime and were active in political and social organisations that were secular and sometimes communist. These traders frequently refer to the agents in Yiwu as 'the 30-year-old hajis', a phrase used to suggest a public commitment to piety does not sit easily alongside being a young man in China. Dur Muhammad for example is a trader aged in his mid-fifties and based in the Ukrainian Black Sea port city of Odessa. During the course of a 10-day visit to Yiwu in the spring of 2016 that he made to purchase the toys he sells in Odessa, Dur Muhammad said to me, 'All of these things about being a hajji is simply a business: one does it so everyone else thinks they have to do it, and now they even compete as to how many times they have been on hajj. Back in Odessa, Dur Muhammad and traders like him regularly organise religious events in one of the two predominantly Afghan mosques in the city. But the ability to host friends and family for dinners and parties in restaurants is considered an equally important way of demonstrating commercial acumen, as well as commitment towards friends and family. Furthermore, traders based in Eurasia are often married to local women who play an active and public role in their joint business activities: if relatively few women staff their husband's shops, many do assist in maintaining accounts and selecting suitable products in which to trade. Some women married to Afghans also accompany their husbands on purchasing trips to the Chinese city of Yiwu.

The performance of trustworthiness and reputability is central to the traders' mode of presenting the self. Yet, complaints about the forms of mistrust that characterise their activities and working lives are also pervasive, especially regarding their relationships with commission workers. Besides being regularly accused of supplying information about the business practices of fellow traders, commission workers are also said to find crafty ways of charging traders more than the actual cost of transporting goods from China to the markets in which they work. Similarly, merchants based in the markets in which Afghans work are frequently said to have secretly undercut the activities of their fellow Afghans, and even their close friends and business partners, in order to insure they establish themselves as the pivot of market pyramids in particular goods, thereby making themselves less vulnerable to the vagaries of the market. Indeed, in the context of the inherent fragility of apparently trust-based and reputationcentred relationships, traders often said to me they would rather not work with their compatriots at all. Dur Muhammad - the trader in toys introduced above for instance chose to employ a Chinese commission agent rather than one of 
his Afghan compatriots based in Yiwu: 'It's impossible to work with Afghans', he said to me, 'they are nothing but trouble'. In the markets in which they work, many traders employ locals rather than Afghans, saying the latter are not only expensive to employ but will also eventually establish a business of their own having learned the secrets of the trade from their employer.

Having explored traders' overarching conceptions of masculinity and familial life in a complex and globalised economy that is nevertheless inflected in a complex way by Asian Islamicate and cultural influences, the article now turns its attention to how traders narrate their intimate family lives, addressing the insights that a consideration of this sphere of life offers into understanding the traders' conceptions of masculinity. The case studies explored all relate to married men from Afghanistan based in Odessa.

\section{Case Study 1: Afghan Family Life in Odessa}

The most established group of traders in the Seventh-Kilometre Market are now in their mid- fifties to late sixties and have been based in Odessa since the early 1990s. Many studied in the city on Soviet bursaries during the 1970s and 1980s, the height of Soviet influence in Afghanistan. These men were affiliated with the pro-Soviet regime (1978-1992) and mostly left the country shortly before or after the collapse of the government of President Mohammad Najibullah in 1992. They are now recognised by Afghans in Odessa as having been the pioneers of the commodity trade with China; it is they who first travelled to China in the early 1990s in order to buy commodities and import them to Ukraine. Other traders in the market arrived in Odessa in the context of later waves of migration from Afghanistan, especially in the wake of the Taliban takeover of the country in the late 1990s. This wave of immigrants is sceptical about the extent to which the first wave of Afghan traders to Ukraine has been faithful to Afghan culture and moral norms. Later migrants argue the experience of being educated and brought up in the Soviet Union weakened earlier migrants' understandings of Afghan culture. They regard this as being most especially the case for men who attended in the 1980s Soviet 'boarding schools' (internat) under bilateral schemes developed by the Soviet and Afghan governments in the 1980s (Nunan 2015). More recent migrants argue Afghans raised in such internat were alienated from their own society and as a result are untrustworthy (beihtibaar) and unreliable (beihtimaad) - in short, unmanly (namard). One trader, for example, left Odessa for Western Europe with money he had taken on loan from several of his compatriots, never to return. It was widely remarked at the time that this absconder had been brought up in an internat and therefore it was inevitable that he had proved himself a person devoid of trust and honourable conduct. How do individuals who were educated in the Soviet Union and have spent much of their lives in the former Soviet world fashion their masculine identities and families lives? 
Dur Mohammad sells toys on a wholesale basis in the Odessa's SeventhKilometre Market. Now in his mid-fifties, Dur left Afghanistan after the collapse of Najibullah's regime in 1992, in which he had served in a variety of roles. $\mathrm{He}$ is married and has two children, both daughters in their late teens: one is currently studying at secondary school and the other at a university in Odessa. The family is regarded as being comparatively successful by the standards of the other four thousand or so Afghans based in the city, most of whom also work in the Seventh-Kilometre Market. Dur Muhammad owns a large and comfortable flat in Odessa. While the flat was built in the Soviet era, the family has earned enough money in the market to renovate their home according to what is referred to in Ukraine and in other post-Soviet settings as European style (evroremont). Dur Muhammad regularly travels to China and has brought back numerous Chinese paintings and prints, which are prominently displayed in the flat; being a trader who 'travels to China' is an important mark of distinction among Afghan traders in Odessa. Perhaps the most important purchase this trader has made in China for his family, however, is a large leather sofa: he was able to fit the sofa inside a container of toys he was importing to Ukraine and thereby avoid paying the country's expensive import duties. In addition to the apartment in which the family lives, Dur Muhammad has also bought a further smaller flat in a newly built apartment block complex. Dur Muhammad told me he had bought the flat so that his daughter could move there when she wishes. Dur Mohammad is keen to demonstrate how he has not only built up a successful family business but also used in a simultaneously clever and resourceful manner the profits from this to support his family.

In terms of his working life, Dur travels at 5 a.m. every day (other than Friday, the weekly holiday of the Seventh-Kilometre Market) to the market to start work, returning home in the mid-afternoon. He occasionally employs a young man to assist him with the management of his shop, most especially by moving boxes of commodities from the warehouse (located a short distance outside the market) to the shop. For some time, Dur Muhammad employed one of his nephews (who had come to Ukraine from northern Afghanistan) as a warehouse keeper (godaamdaar). The relationship between uncle and nephew, however, had not been easy: Dur Muhammad regarded his nephew as being highly religious; according to Dur Muhammad, he acted, for example, as though he was shocked by the way Dur's daughters and wife dressed in European clothing and went unveiled (behijaab) in public. Eventually, the nephew left Odessa for Denmark, where he filed an asylum case. As do many other Afghan traders in the city, Dur Muhammad emphasises that that if popular perceptions of traders often present such folk as magically making money out of thin air, the reality is one in which success is possible only with challenging work and labour.

Dur plays a lively role in the dynamics of community life in Odessa. He is a member of a 'fund' - a type of community organisation that collects monthly donations from Afghan traders based in Odessa and uses these to 
assist compatriots facing financial difficulties such as bankruptcy resulting from warehouses fires. Dur also assists in the organisation of collective events for the Afghan community. On the death of his father in Afghanistan, for example, he spent nearly $\$ 5,000$ on a sacrificial feast (qurbani) for members of Odessa's Afghan community: the feast was held at a mosque that is predominantly attended by Afghans. He is also a well-known participant at the community events organised by Odessa's Afghans. Dur Muhammad regularly acts, for example, as the compere at ceremonies held in the city to mark the death anniversaries of notable politicians from Afghanistan. His command of formal Farsi and his background of being a high-ranking state servant in Afghanistan are regarded as uniquely qualifying him for such a role. Dur Muhammad has also played an active role in helping arrange for the delivery of donations from Odessa's Afghan community to the region of Afghanistan from which he hails, most recently after it's villages were hit by a deadly series of landslides. He has also made substantial donations to religious authorities in his home region upon being contacted by them to request support for mosque and madrasabuilding projects. According to Dur Muhammad, as a result of making substantial donations, there is now even a mosque in the region that bears his name.

Dur Muhammad invests a great deal of effort into enacting and sustaining a model merchant identity rooted in reputation and trustworthiness and performed in the idioms, symbols and practices of Islam. He successfully fulfils the role of a provider for his wife and family; he leads a hard-working life that alternates between the market and the home, and pivots around the ideals of social reputability and trustworthiness, and he uses his free time and available resources to support not only his direct kin in Afghanistan but also traders from Afghanistan based in Odessa, as well as the people of his home region more generally.

Yet, in specific respects, Dur Muhammad's self-presentation also departs from this carefully cultivated image of the reputable Muslim merchant. I have already mentioned Dur Muhammad's uneasy relationship with his brother's son, whom he regards as being excessively religious and narrow-minded, especially in terms of his thinking about the status and role of women in society. At the same time, while Dur Muhammad is an integral part of the closely knit community of traders from Afghanistan in Odessa, he also acts in a manner that challenges a simple understanding of him being an embodiment of its 'dominant' conception of masculinity. Most importantly, Dur Muhammad is one of the few traders from Afghanistan active in the Seventh-Kilometre Market who works alongside his wife in a shop (dukaan) they jointly run. While most Afghan traders rarely if ever bring their wives to the market, let alone work alongside them in their shops, Dur Muhammad's wife is an everpresent feature in the container that serves as the couple's shop. Moreover, during the long summer vacations his elder daughter - a university student - is often also to be seen lending her father and mother a helping hand. Beyond merely assisting Dur Muhammad in his trading activities in the shop itself, his 
wife and daughters play an active role in procuring the commodities in which the family traders. Over the past 12 years, Dur Muhmmad has mostly made such two-week trips on his own, occasionally taking his wife. In 2016, however, with the aim of further encouraging his elder daughter to develop an interest in the family's commercial activities, Dur Muhammad and his wife and daughters collectively decided the three women of the family would travel to China to purchase the toys and arrange their shipment from Yiwu to Odessa. They would be helped by a Chinese woman rather than an ethnically Afghan commission agent. While the women of the family were in China, Dur Muhammad stayed in Odessa operating the shop. He also transferred cash from Odessa to Yiwu to pay for the commodities his wife and daughter purchased.

Dur Muhammad was, however, very careful to keep all information about his wife and daughters' trip to Yiwu secret from even his closest of Afghan friends in Odessa. He said to me one day that 'the views of these Afghans are very backward and dark, as opposed to mine; I have worked for the rights of women and for women of Afghanistan to have the same rights as women elsewhere. During their stay in Yiwu, Dur Muhammad's daughters and wife did not establish contact with any of Dur Muhammad's many Afghan associates (ashnaahaa) in the city, preferring to maintain an active distance between themselves and the city's Afghans. Many of Yiwu's Afghan traders indeed hold and express conservative ideas about the extent to which Afghan women in the city should lead pubic lives. A trader from central Afghanistan, for example, told a group of traders from Afghanistan gathered in a cafe in Yiwu that on bringing his wife to Yiwu from Afghanistan the previous year, he had told her directly that she should not expect him to take her out or to go shopping or to do anything in public together: 'This is your flat', he said to her, 'and this is where you will stay'. After the woman's one-year visa had run out, he asked whether she would prefer to stay in Yiwu or return to Afghanistan: she chose the latter option. Similarly, a trader from another district in central Afghanistan said to a gathering of traders in Yiwu that the fact that Afghan woman were never seen with their husbands in Yiwu demonstrated how Afghans had successfully 'preserved' (nigaah kardand) their culture (farhang), something he contrasted with Iranians living in the city who regularly appeared in public with their wives in the city's social spaces. Dur Muhammad's decision to encourage his wife and daughters to travel to China in his absence represents a significant diversion from the conventional practices of Afghan traders based both in Odessa and Yiwu. But simultaneously he sought to maintain a public level of commitment to religious and culturally sanctioned images of respectable family life.

Like many men of his generation in Ukraine, Dur Muhammad is married not to an Afghan but to a woman he met in the post-Soviet world. Dur Muhammad met his wife (Gulnaz) in the Caucasus during the early 1990s; other Afghans in Odessa are married to ethnically Russian, Turkish and Armenian women (cf. Marsden and Ibanez Tirado 2015). The traders often 
remark about how 'foreign wives' play a generally different role in the public life of men from Afghanistan than is the case for men married to Afghan women. Gulnaz's non-Afghan background is a major factor that enables her to work in the market alongside him and to travel to China to oversee the couple's business activities. Dur Muhammad told me their decision to work together goes back to the early days of their entering the market in Odessa as traders. With very little capital, they launched a business in the market and were unable to pay for childcare for their daughters; they could only maintain the business because both husband and wife worked in the shop and contributed to the care of their small children. Dur Muhmmad regularly emphasises the amount of time and energy he invested to caring for his children when they were infants, often remarking, 'I carried these children and brought them up!'

'Foreign wives' (zan-e khaariji) appear alongside their husbands at public events such as communal picnics or dinner gatherings involving traders whose business and family ties are especially close. By contrast, women from Afghanistan married to Odessa-based Afghans rarely if ever accompany their husbands to such events, attending instead only gatherings to which close family members have been invited. Importantly, this distinction is not simply down to the views that men in the community hold about the acceptability of women appearing in public according to either cultural or Islamic traditions. It is normal, for example, for women from Afghanistan based in Odessa to take their children to one of the city's many parks, either alone or with other Afghan women. Rarely, however, do Afghan women appear in public in the company of their husbands. At stake, then, is the co-presence of a man and his wife in public space: being seen with an Afghan wife makes it possible for the woman to be identified by non-related Afghan men, thereby placing restrictions on a woman's ability to both remain invisible and move around the city should her husband not be present. If Afghan men married to 'foreign wives' socialise with them in public (such as on the beach or in the city's cafes and restaurants they enjoy frequenting), then the market is a space in which even 'foreign wives' rarely play a prominent or public role. Dur Muhammad challenged this boundary, regularly telling me he was putting into practice the ideas he had held since joining Afghanistan's leftist political movement.

A key aspect of how Dur Muhammad and traders of similar backgrounds enact their masculinity in Eurasia is through the public performances of adaptability. In terms of his relationship with both his wife and his daughters, Dur Muhammad emphasises his capacity to enact modes of familial and business life that reflect the situation in which he lives, as well as the shifting desires and aspirations of his family. Rather than solely reflecting a tension between individual subjectivity and cultural idioms, Dur Muhammad's enactment of shifting forms of masculinity reflect the influence of his political background and the ways this informs his understandings of the good life. Importantly, however, Dur Muhammad is also sensitive to the broader Afghan cultural world in which he works and earns a living. 


\section{Case Study 2: Divorce and Childcare}

Having explored the case of how an established trader looks back at his life and relationships within his family, as well as conducts business alongside them in a globalised economy today, the article now explores the case of a merchant who belongs to the generation of Afghans who came of age in the 1990s after the collapse of the pro-Soviet regime of Najibullah. This generation of traders often consists of the sons or nephews of men affiliated with the pro-Soviet government: influenced by their fathers' thinking on social and political concerns, they have nevertheless embarked on working and family life in post-Soviet environments. ${ }^{3}$ This section will explore men of this age through a consideration of a middle-aged trader who is a father of two daughters yet separated from his wife. The trader is currently bringing up his children alone, having sought and earned refugee status in the Netherlands.

Farhan is from north-western Afghanistan and in his early forties. Having left Afghanistan with his family in 1992 for Pakistan, Farhan lived in Turkmenistan in the late 1990s and early 2000s, where he married a woman of Turkmen nationality with whom he had two children. In the mid-2000s however, Farhan was left with no other option than to leave behind his wife and daughters in Turkmenistan: the country's government had introduced legislation that made it substantially more difficult for Afghans to be awarded visas and residency permits and thus to base themselves in the country, or, indeed, operate their own businesses and trading enterprises there. Farhan often emphasised to me and his Afghan friends that it was he who brought up his two girls (now aged 12 and 15), rather than their mother. Farhan and his wife considered the option of moving to Afghanistan, a country to which they travelled together with their children for a short visit. The couple agreed, however, it would be impossible to raise their children in Afghanistan. Farhan, whose father and uncles were state officials in the pro-Soviet government of the 1980s, holds and openly voices liberal, secular and leftist ideas, while his then wife was accustomed to life in formerly Soviet contexts. Farhan said to me 'I wouldn't have survived more than a couple of weeks in the town in which I was born once the type of remarks I make about religious issue had been reported to local mullahs.

Farhan decided to move from Turkmenistan to another Muslim-majority state in the former Soviet Union: Tajikistan. When he moved in 2009, the country had a good reputation among Afghans for being a setting in which traders could establish a family and set up an import business with relatively little capital. Over the course of some seven years, Farhan engaged in a range of commercial activities in Tajikistan, including the import of Pakistani tangerines and Iranian citrus fruit and processed food products. During this time, Farhan mostly lived apart from his wife and children, who remained in Turkmenistan, although they did make several short trips to see him. Farhan earned a great reputation during this period among his Afghan and Tajik friends and business partners for his homeliness, domesticity and unrelenting hospitality. He always 
ensured guests to his house were carefully cared for and that the series of rented apartments in which he lived were kept clean and respectable. For Farhan, far from being a simple vehicle to demonstrate patriarchal control and authority, being hospitable allowed him to enact and demonstrate affection and care for his circle of friends and associates in Dushanbe. Overall, Farhan's meticulous approach to home life was respected by the men with whom he lived, although he was occasionally accused of being too strict in his attitudes to household cleanliness: some poured scorn on what they saw as being his overly zealous feminine habits.

In the context of this extended period of living apart, Farhan and his wife's relationship underwent considerable difficulties. Eventually, Farhan's wife refused to bring his children to see him in Tajikistan. Keen to be reunited with his children and concerned about their situation, as well as the parenting style of the girls' mother, Farhan travelled to Afghanistan with the aim of securing a Turkmenistan visa. Having spent several weeks in Afghanistan in the summer of 2011, he was unable to get a visa that would allow him to be reunited with his children, even though he had sought the support of the International Organization for Migration and Afghanistan's Ministry of Foreign Affairs. Over the course of several months, Farhan attempted to persuade his wife to visit Tajikistan with his children. Unexpectedly, Farhan's wife arranged for the daughters to travel to Tajikistan along with their aunt, but in her absence; she also gave the children permission to live with their father.

In 2015, Farhan left Tajikistan, with his daughters. Farhan moved with his two daughters from Tajikistan to the Netherlands using an overland route and in order to do so, paid for the services of several 'people smugglers'. In the process, he lost much of the capital to which he had access in Tajikistan. Having lived for some months in a refugee detention centre, Farhan had been awarded residency documents in the Netherlands and now looked after his two daughters, attended Dutch language classes, while also finding time for one of his favourite activities: judo. Farhan was relieved he had left Tajikistan, where it has been getting harder and harder for Afghans living in the country to work and trade. Yet, he also believed coming to the Netherlands was the waste of a life for a man of his age and background. He did not have sufficient capital to launch a business in the country, yet not having been formally schooled and being unable to speak Dutch meant that at best, he might eventually one day earn employment as a machine operator or a heavy goods vehicle driver. Farhan had also come to realise he had little time for any activities other than caring for his two daughters - whom he needed to have ready for school in the morning and be present at home in the afternoon in order to host the various teachers assigned to help them with their studies on an out-of-school basis. The move from Tajikistan to the Netherlands, he told me, had thus been made solely with the long-term interests of his daughters in mind: his days of being an independent trader were now over. Instead, he was grappling with the multiple difficulties that came with being officially designated as a 'refugee'. 
There are important continuities in the case of Dur Muhammad and Farhan - notably the public criticism of conventional Afghan gender norms based on 'leftist' and avowedly 'modern' forms of political ideology and affiliation. Yet, there are also divergences in the men's modes of enacting masculinity. Dur Muhammad sought to negotiate between demonstrating commitment to the normative cultural and religious idioms of 'Afghan' masculinity and family life important for the traders with whom he works. By contrast, in Farhan's case, mobility, the unpredictable circumstances of family life and the need to operate within rigid international migration regimes resulted in him adapting to form of family life at odds both with Afghan cultural and normative idioms, but also with the perceived independence of being a trader.

\section{Case Study 3: War, Migration and Marriage}

The final case study concerns Mansour, a Dari-speaking man from eastern Afghanistan in his late twenties who now lives in Odessa. If the earlier ethnographic examples point to the importance of recognising ideology and historic forms political affiliation to traders' social enactment of masculinity, then Mansour's case illustrates the significance of 'inner conflicts' between individuals and the 'strict cultural idioms' concerning masculine conduct and behaviour they are expected to enact (Chiovenda 2018). Mansour came of age in the years after the collapse of the Taliban government and in the context of the presence of international forces in Afghanistan. Mansour himself had worked with the US military in Afghanistan, serving as an interpreter. He left Afghanistan having completed his work with the United States in 2011. During his years of employment, he had been able to earn a decent living in US dollars, which he had partially invested in travelling with his wife and her small child to Ukraine, as well as in launching a small-scale business in the Seventh-Kilometre Market.

Mansour has now been based in Odessa for five years: he runs a wholesale bag and handbag business from a container in the market that he rents. Mansour does not import bags from China himself but rather procures them on a credit basis from a range of importers, including those from Afghanistan and China, as well as Ukraine; he then sells them on a retail basis from his own container. This means that while able to pass a reasonably stable life with his family, Mansour is not regarded as being especially successful by other Afghan traders in the market: he is representative, rather, of the most recent wave of migrants to the city from Afghanistan, many of whom had been employed in similar jobs in Afghanistan.

Before moving to Afghanistan, Mansour worked as a translator (tarjaaman) with a battalion of the US Army who were stationed in Afghanistan. Towards the end of the deployment of the US forces with whom he was working, Mansour was informed he would be eligible to apply for resettlement in the 
United States. The commander of the unit warmly supported Mansour's application for resettlement, commending the work he had undertaken with the US soldiers. Mansour left Afghanistan for Ukraine having submitted the application, hoping he would receive his travel documents while in Odessa and be able to move from Ukraine to the United States.

Mansour's case, however, had been slowed down because of a significant difficulty that had emerged after the documents were submitted. When filling in the form to apply for resettlement, Mansour had indicated he was unmarried. In reality, however, he had married about a year before completing the application. Mansour told me he had decided not to include details of his marriage on the forms. This was not because he wished to lead the life of a single man (mujarrat) in the United States. Rather, Mansour had been asked a year earlier by his family to marry his deceased brother's wife after he had been killed in an aeroplane crash in Afghanistan, leaving behind a wife and small child. In the wake of the death of his son, and fearful about the future of his daughter-in-law and granddaughter, Mansour's father requested Mansour marry his brother's wife, in order to insure the future welfare of mother and daughter. Mansour told me he had found the idea very difficult to accept: it had long been his ambition to marry a woman of his own choice; he was unable to see how a good relationship could develop between a couple if the only thing that drew them together was his brother's death. Mansour described to me the feeling of shame or embarrassment (sharm) he felt when thinking of informing his US employees of his decision to agree with his father's demand that he marry his deceased brother's wife; as a result, he had neglected to include it on his resettlement application.

When we first met in 2013, Mansour was looking after his brother's daughter and his now wife, while she was also expecting the couple's first child together. On meeting Mansour again four years later, the couple now had three children living with them in Odessa; they remained unable to leave Odessa for the United States. Like many other Afghans in Odessa, Mansour was unclear as to what course of action he should take regarding his family and their future in Ukraine. The security situation in Afghanistan continued to be fraught and his father advised him not to return to the country. Mansour was also ambiguous in terms of his thinking about life in Odessa. On the one hand, he was undecided as to whether to invest in a house for his family in Odessa. Part of him felt it would be impossible for them to lead the life they did in Odessa in Western Europe, where - as in the case of Farhan - he would find it difficult if not impossible to run a business with the small amount of capital he had at his disposal. On the other hand, the general political and economic situation in Ukraine remained unstable in the years following the 2014 annexation of Crimea by Russia: the value of the local currency remained weak, making investing in the sale of imported goods especially volatile, and the business of purchasing a house risky.

Mansour's experiences highlight many of the complex and contradictory pressures that have affected the married lives and masculine identities of 
Afghans brought up in the 'post-Taliban' era. Men such as him have been directly involved in military conflict and the forms of hyper-masculinity that are inevitably a feature of the international labour market; they have also interacted closely with international troops who often vocalise simplified understandings of Afghan modes of being masculinity. At the same time, access to US dollar wages led to rising expectations by men of Mansour's generation regarding their personal autonomy (especially in relation to choices about the domain of marriage and intimate life). Mansour's case is an important reminder, however, of the fact that the inner tensions arising from this context do not necessarily relate in individuals 'defying cultural idioms' and positioning themselves as 'agents for social change' (Chiovenda 2018: 66). Rather, conflict and political uncertainty within Afghanistan has resulted in older modes of organising family life and obliging moral responsibilities being injected with renewed significance.

\section{Conclusion}

A great deal of recent anthropological work on Afghanistan explores the gendered inflections of social transformations that have arisen during the past 17 years of international intervention (e.g. Billaud 2015). There is also recognition of how Afghanistan's contemporary gender dynamics have been influenced by multiple geographical, political and historical dynamics (e.g. Kandiyoti 2007). The forms of masculinity and family life enacted by the trading networks and mobile societies documented in this article reflect this multiplicity. The trading networks explored in this article illuminate the simultaneous importance of multiple ideas and models of family life and the forms of masculinity for Afghan traders today. Such models, I have argued, derive in important ways from Islamicate conceptions of ordered sociality and morality. But they are also powerfully inflected by various iterations of Afghan culture, as well as the legacy of the Cold War and socialist politics, and the current international intervention in Afghanistan.

The men whose conceptions of masculinity and family life have been explored here, moreover, not only traverse Eurasia: they live for prolonged periods in the contexts in which they are based. As a result, by following their trajectories, it is possible to track the shifting ways in which the traders enact and perform their masculinity. Ethnographically, the article has demonstrated that traders navigate their performance and enactment of multiple models of masculinity in relationship to their shifting life histories, and the specific places in which they live and work. Focusing on the shifting performance of masculinity across space and time reveals a methodological contribution to literature on migration and masculinity: studies of men after marriages reveals aspects of masculinity's relationship to mobility that are less clearly evinced in research focusing on young migrants. Furthermore, documenting the experiences of 
men from different generations enables scholars to chart change and continuity in the enactment of masculinity, and explore how the tensions between culturally sanctioned models of masculine behaviour and those that are enacted by individuals in daily life manifest themselves in variable ways for different generations.

Across the case studies explored, the performance and enactment of manhood involves a subtle interplay between two connected yet different poles of Afghan men's experience: the ability to fulfil the obligations of the supportive breadwinner, on the one hand, and, on the other, the ability to respond to calls made by wives, children, extended families and overseas compatriots to play a substantial role in the provision of intimate forms of care and caring - for children, for women and for wider commercial networks. Shifting focus away from 'migration' as a two-directional series of movements between home and abroad reveals the flexibility and adaptability of Afghan masculinity, demonstrating how this flexibility emerges in relationship to the normative and economic characteristics of specific geographical contexts. The notion that mobile men inevitably seek to deal with diversity, complexity and rupture in their intimate lives through the demonstration and enactment of hyper-masculinity or inevitably experience such rupture in the form of a 'male crisis' has been widely contested. A consideration of the intimate relationships and masculinities of Afghan traders suggests, instead, that they widely regard dealing in a flexible manner with unfolding situations as both a pragmatic and moral imperative.

\section{Acknowledgements}

I would like to thank Paul Anderson and David Henig for offering critical comments on an earlier version of this article. The research upon which it is based would not have been possible without funding from the Research Council of Norway held by the Chr. Michelsen Institute in Bergen and the Peace Training and Research Organisation in Kabul. I am grateful to Torunn Wimpleman and Aziz Hakimi for including me in the project. The fieldwork on which it is based has additionally been made possible by a European Research Council under the European Union's Horizon 2020 research and innovation programme 669132 - TRODITIES, 'Yiwu Trust, Global Traders and Commodities in a Chinese International City'. Following anthropological convention, pseudonyms are used to refer to all people in this article. In order to preserve anonymity, changes have also been made to the details of the life histories discussed within. 
Magnus Marsden is Professor of Social Anthropology and Director of the Asia Centre at the University of Sussex. He has conducted extensive fieldwork in Afghanistan and Pakistan, and worked on ethnographic projects in Uzbekistan, Tajikistan, Ukraine and China. He is the author of Trading Worlds: Afghan Merchants across Modern Frontiers (2016). Email: m.marsden@sussex.ac.uk

\section{Notes}

1. An extensive body of literature exists on the importance of various forms of trust to the activities of traders and trading networks (see e.g. Aslanian 2012; Carrier 2016).

2. On the importance of mobility at the global scale to Afghan history and society, see Crews (2015); Marsden (2016); Monsutti (2018).

3. On the problematic nature of the distinction between Soviet and post-Soviet, see Ibanez Tirado (2013).

\section{References}

Abu-Lughod, L. (1986), Veiled Sentiments (Berkeley: University of California Press).

Anderson, P. 2011. 'Threads of virtue: the ethical lives of Syrian textile traders', Unpublished PhD Thesis, University of Edinburgh.

Anooshahr, A. (2008), 'The King Who Would Be Man: The Gender Roles of the Warrior King in Early Mughal History', Journal of the Royal Asiatic Society 18, no. 3: 327-340, https://doi.org/10.1017/S1356186308008547.

Aslanian, S. D. (2014), From the Indian Ocean to the Mediterranean: The Global Trade Networks of Armenian Merchants from New Julfa (Berkeley: University of California Press).

Billaud, J. (2015), Kabul Carnival: Gender Politics in Postwar Afghanistan (Philadelphia: University of Pennsylvania Press).

Brenner, S. (1998), The Domestication of Desire: Women, Wealth, and Modernity in Java (Princeton, NJ: Princeton University Press).

Carrier, N. (2016), Little Mogadishu: Eastleigh, Nairobi's Global Somali Hub (London: Hurst \& Co.).

Chiovenda, A. (2018), 'Shaping a "Different” Masculinity: Subjectivity, Agency, and Cultural Idioms among Pashtun Afghan Men', in Reconceiving Muslim Men: Love and Marriage, Family and Care in Precarious Times (ed.) M. Inhorn and N. Naguib (New York: Berghahn Books), 63-84.

Connell, R. W. and Messerschmidt, J. W. (2005) 'Hegemonic Masculinity: Rethinking the Concept', Gender and Society 19, no. 6: 829-859, https://doi.org/10.1177 10891243205278639. 
Crews, R. (2015), Afghan Modern: the History of a Global Nation (Cambridge, MA: Harvard University Press).

Dresch, P. (1998), 'Mutual Deception: Totality, Exchange and Islam in the Middle East', in Marcel Mauss: A Centenary Tribute, (ed.) W. James and N. Allen (New York: Berghahn Books), 111-33.

Edwards, D. (1996), Heroes of the Age: Moral Faultines on the Afghan Frontier (Berkeley: University of California Press).

Ferdinand, K. (2006), Afghan Nomads: Caravans, Conflicts and Trade in Afghanistan and British India 1800-1980 (Copenhagen: Rhodos International).

Geertz, C. (1973), 'The Bazaar Economy: Information and Search in Peasant Marketing', American Economic Review 68, no. 2: 28-32.

Hanifi, S. M. (2011), Connecting Histories of Afghanistan (Stanford, CA: Stanford University Press).

Harpviken, K. B. (2009), Social Networks and Migration in Wartime Afghanistan (London: Palgrave Macmillan).

Ho, E. (2017), 'Inter-Asian Concepts for Mobile Societies', Journal of Asian Studies 76, no. 9: 907-928.

Hopkins, B. D. (2009), The Making of Modern Afghanistan (London: Palgrave Macmillan). Ibanez Tirado, D. (2015), “'How Can I Be Post-Soviet if I Was Never Soviet?' Rethinking Categories of Time and Social Change - A Perspective from Kulob, Southern Tajikistan', Central Asian Survey 34, no. 2: 190-203, https://doi/abs/10.1080/ 02634937.2014.983705.

Ingvars, A. K. and Gíslason, I. V. (2018), 'Moral Mobility: Emergent Refugee Masculinities among Young Syrians in Athens', Men and Masculinities 26, no. 1: 3-19, https://doi.org/10.1177/1097184X17748171.

Inhorn, M. C. (2012), The New Arab Man: Emergent Masculinities, Technologies, and Islam in the Middle East (Princeton, NJ: Princeton University Press).

Inhorn, M. C. and Isidoros, K. (2018). 'Introduction', Men and Masculinities 26, no. 1: 3-19, https://doi.org/10.1177/1097184X17748168.

Kandiyoti, D. (2007), 'Between the Hammer and the Anvil: Post-conflict Reconstruction, Islam and Women's Rights', Third World Quarterly 28, no. 3: 503-517, https:// doi.org/10.1080/01436590701192603.

Khan, N. (2014), 'The taste of freedom: commensality, liminality, and return amongst Afghan transnational migrants in the UK and Pakistan', Journal of the Royal Anthropological Institute 20, no. 3: 466-485, https://rai.onlinelibrary.wiley.com/doi /full/10.1111/1467-9655.12115.

Kurin. R. (1984), 'Islamization in Pakistan: A View from the Countryside', Asian Survey 25, no. 8: 852-862.

Lindholm, C. (1982), Generosity and Jealousy: The Swat Pukhtun of Northern Pakistan (New York: Columbia University Press).

Malik, I. (2016), Pashtun Identity and Geopolitics in Southwest Asia (London: Anthem Press).

Marsden, M. (2005), Living Islam: Muslim religious experience in Pakistan's North West Frontier (Cambridge: Cambridge University Press).

Marsden, M. (2007), 'All-Male Sonic Gatherings, Islamic Reform, and Masculinity in Northern Pakistan', American Ethnologist 34, no. 3: 473-490, https://doi.org/10.1525/ ae.2007.34.3.473. 
Marsden, M. (2008), 'Muslim Cosmopolitans? Transnational Life in Northern Pakistan', Journal of Asian Studies 67, no. 1: 213-248, https://doi.org/10.1017/ S0021911808000077.

Marsden, M. (2016), Trading Worlds: Afghan Merchants across Modern Frontiers (London: Hurst \& Co.).

Marsden, M. and Ibanez-Tirado, D. (2015), 'Repertoires of Family Life and the Anchoring of Afghan Trading Networks in Ukraine', History and Anthropology: 26, no. 2: 145-164, https://doi.org/10.1080/02757206.2014.1002375.

Mathews, G., Lins Ribeiro, G. and Alba Vega, C. (2012), Globalization from Below: The World's Other Economy (London: Routledge).

Monsutti, A. (2006), 'Migration as a Rite of Passage: Young Afghans Building Masculinity and Adulthood in Iran', Iranian Studies 40, no. 2: 167-185, https://doi. org/10.1080/00210860701276183.

Monsutti, A. (2018) Homo itinerant: Planète des Afghans (Paris: Presses Universitaires France).

Naguib, N. (2015), Nurturing Masculinities: Men, Food, and Family in Contemporary Egypt (Austin: University of Texas Press).

O'Hanlon, R. (1999), 'Manliness and Imperial Service in Mughal North India', Journal of the Economic and Social History of the Orient 42, no. 1: 47-93, https://doi. org/10.1163/1568520991445597

Osella, F. (2013), 'Malabar Secrets: South Indian Muslim Men's (Homo)sociality across the Indian Ocean', Asian Studies Review 36, no. 4: 531-549, https://doi.org/10.1080 /10357823.2012.739996.

Osella, F. and Osella, C. (2007), "I Am Gulf”: The Production of Cosmopolitanism in Kozhikode, Kerala, India, in Struggling with History: Islam and Cosmopolitanism in the Western Indian Ocean, (ed.) K. Kresse and E. Simpson (London: Hurst \& Co.), 323-355.

Peletz, M. G. (1994), 'Neither Reasonable nor Responsible: Contrasting Representations of Masculinity in a Malay Society', Cultural Anthropology 9, no. 2: 135-178, https:// doi.org/10.1525/can.1994.9.2.02a00010.

Picard, E. (2006), 'Managing Identities among Expatriate Businessmen across the Lebanon-Syria Boundary' in State Frontiers: Borders and Boundaries in the Middle East, (ed.) I. Brandell (London: I.B. Tauris), 75-99.

Prat-Ewing, K. (2008) Stolen Honour: Stigmatizing Muslim Men in Berlin (Stanford: Stanford University Press).

Schielke, S. (2009), 'Ambivalent Connections: Troubles of Morality, Religiosity and Aspiration among Young Egyptians', Journal of Religion in Africa 39, no. 2: 158-185.

Schielke, S. (2015) Egypt in the Future Tense: Ambivalence, Hope and Frustration in Egypt before and after 2011 (Bloomington: Indiana University Press).

Siegal, J. (1969), Rope of God (Berkeley: University of California Press).

Suerbaum, M. (2018), 'Becoming and "Unbecoming" Refugees: Making sense of Masculinity and Refugeness among Syrian refugee men in Egypt', Men and Masculinities 26, no. 1: 363-382, https://doi.org/10.1177/1097184X17748170.

Tapper, Richard. (2008), 'Who are the Kuchi? Nomad self-identities in Afghanistan', Journal of the Royal Anthropological Institute, 14, no. 1: 97-166, https://doi.org /10.1111/j.1467-9655.2007.00480.

Vom Bruck, G. (2005), Islam, Memory, and Morality in Yemen: Ruling Families in Transition (London: Palgrave Macmillan). 